\title{
LA-5458-MS
}

INFORMAL REPORT

Relationship of Self-Focusing to

Spatial Instability Modes 
This report was prepared as an ancount of work sponsored by the United States Government. Neither the United States nor the United States Atomic Energy Commission, nor any of their employees, nor any of their contrac. tors, subcentractors, or their employass, makes any warranty, express or im. plied, or exumes any legal liability or responsibility for the accuracy. com. pleteness or usefulness of anv information, apparatus, product or process disclosed, or rapresents that its use would not infeinge privately owned rights.

In the interest of prompt distribution, this LAMS report was not edited by the Technieal Intormation staff.

Printed in the United States of Americs. Availabie from

National Technica! Intormation Service

U. S. Department of Commere

5285 Port Royal Rowt

Springfield, Virginis 22151

Price: Printed Copy S4.00: Mierofiche \$1.45 


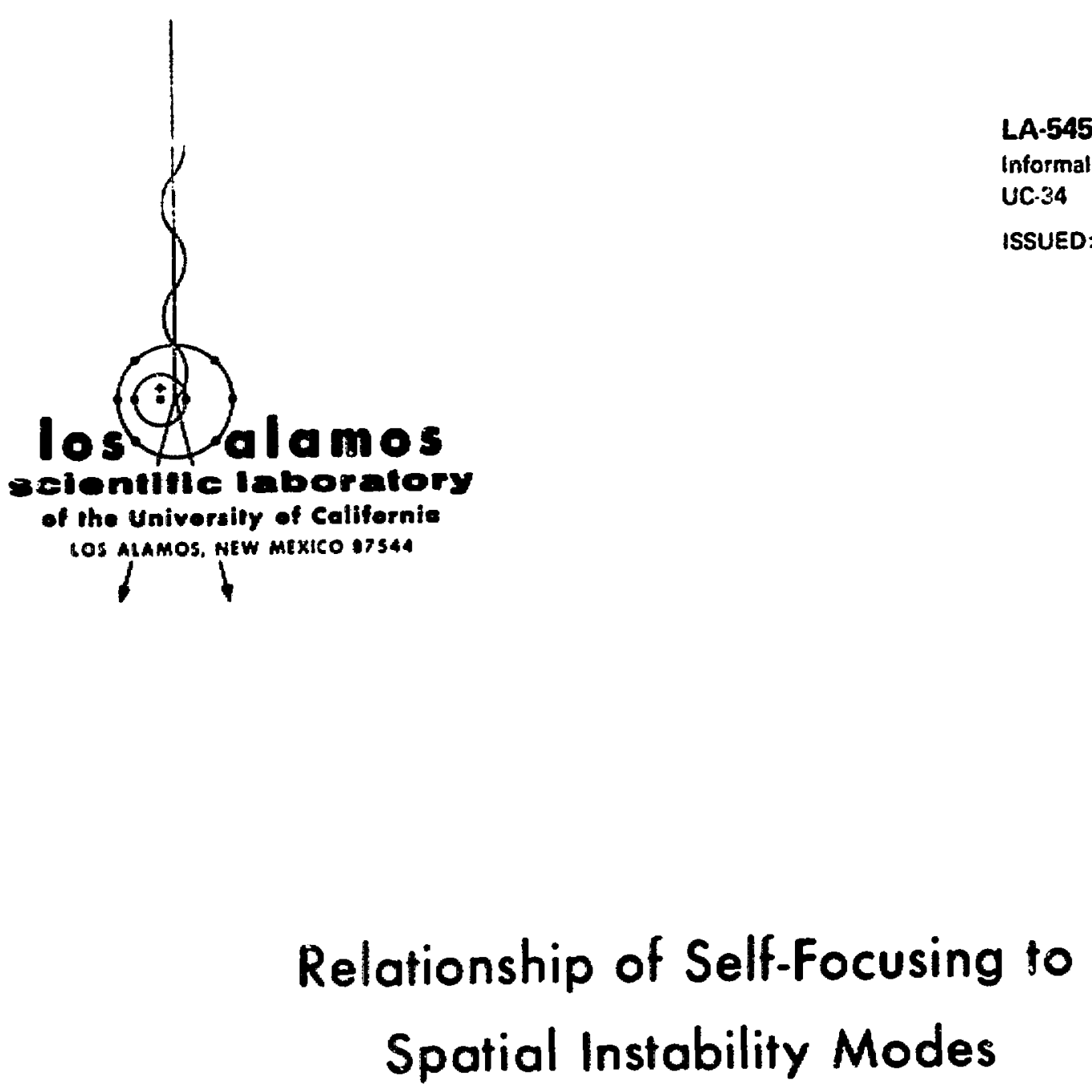

LA.5458-MS

Informal Report

SUED: November 1973

\section{Relationship of Self-Focusing to Spatial Instability Modes}

by
A. J. Campillo
S. L. Shapiro
B. R. Suydam

This tegod was ptepared as an accouns of mok

Fonsered by the United Siates Government. Neithet

the Unlied Stalds nor ine United stules Atomit Eneray

Commitsion, nor any of thet employest, nor eny of

Ihat contfaclors, subeontinctors, of thet imptoyees,

mskes any wrransy, express or impled, or surumes any

ted listilis of responsibitily for the occurecy. com.

tetents of userulnas of eny information, appivatus

produet of pocess distosed, of reprevants inst its use

woutd not infinge privitely owned eishes. 
RELATIONSHIP OF SELF-FOCUSING TO SPATIAL INSTABILITY MODES

by

A. J. Campi:10, S. L. Shapiro, and B. R. Suydam

\section{ABSTRACT}

The spatial distribution of focal spots formed when laser beans self-focus in materials is shown to originate from the growth of certain instability modes. These nodes aro derergined by a siaple mathemasical rclationship derived from instability theory, which has been verified experimentally. Because of these instabilizies, the chreshold power for self-focusing is inversely proportional to the self-focusing length for high-power laser beams.

we have shown recenely' that high-power laser beams break up into cells whose size is in accord with theory ${ }^{2,3}$. Experimentally this was demonsiated by allowing a diffraction pactern to self-focus, and then letring the bean divide into cells whose size was determined by the fastest growing instability mode. This dominate mode outgrew all the other modes when amplitude and phase Eluctuations on the boan were due only to, e.g. , refractive index inhomogeneities, dust, or spontancous noise. However, a less swiftly groving mode can dominate if the initial bean profile has a large applitude component corresponding to the frequencies of that mode. Linear stability theory predicts that ar initial disturbance $\delta E_{0}$. of the field $E_{0}$, of transverse wave number vec$\operatorname{tor}^{4} k=\left(k_{x}, k_{y}\right)$, will grow as exp (az) as it travels in the 2 direction, and the gronth rate $\alpha$ is given by

$a=\frac{c}{2 w n_{0}} k\left(2 y\left|E_{0}\right|^{2}-k^{2}\right)^{1 / 2} ; k^{2} \equiv k_{x}^{2}+k_{y}^{2}$,

$$
y \equiv \frac{3 \omega^{2}}{2 c^{2}} n_{0} n_{2}
$$

where $n_{2}$ is the usual coefficient of the nonlinear part of the refractive index, e.g., $n=n_{0}+n_{2}|E|^{2}$. According to the linear theory al! modes with the same value of $k^{2}$ grow at the same rate, and those modes for which

$k^{2}=k_{m}^{2} \equiv \gamma\left|E_{0}\right|^{2} ; a_{m}=c k_{m}^{2} /\left(2 \omega n_{0}\right)$

grow the fastest, and will normally outstrip all others. Once the perturbation becones large, it starts =o interact with itself. During this nonlinear phase its growth becomes more rapid than exponential, and the nost compact modes, i.e., those for which $k_{x}=k_{y}$. grow fasecst. This rapid nonlinear groweh leads to self-focusing in a finice distance $z_{f}$, which our theory gives as $^{2}$

$z_{f}=\left(1 / a_{m}\right) \log (3 / \delta)=\frac{10^{-7} \mathrm{cn}_{0}}{G \pi n_{2}}\left(\frac{\mathrm{c} / \omega}{\mathrm{I}}\right) \log (3 / \delta)$.

where I is the intensity of the bean in wates/cm ${ }^{2}$ and 6 measures the initial perturbation, i.e.. $\delta\left|\delta E_{0}\right| /\left|E_{0}\right|$, or alectratively 6 is the phase perturbation in radians. It is the purpose of this leter 
to show that when a Gaussian bean of many critical powers propagates through a medium, it indeed breaks up into cells of wave number vector $k_{m}$, provided there is no gross perturbation on the initial beam. Each cell of the break-up pattern produces a selffocus and from the pattern of self-focal spots one can measure separately $k_{x}$ and $k_{y}$ and hence determine $k^{2}$.

The mode with maximum growth rate depends on $k_{x}$ and $k_{y}$, and both must be measured to verify Eqs. 1 and 2. One method of verifying these equations is to experimentally select a $k_{x}$ by amplitude modulation of the beam in the $x$-direction, allowing $k_{y}$ to be freely determined by the instabilities and to be measured from the spacing of the spots formed due to self-focusing. This artifice aids in accurately determining $k_{x}$ and $k_{y}$ by forcing the beam to break up into cells of rectangular shape. Then the dependence of $k^{2}$ on the intensity can be determined experimontally. As the intensity of the beam is increased, the self-focusing length decreases, and many sample cells of different length must therefore be used to determine the relationship between $k$ and intensity. Note that there is an instability mode with a k-vector that grows the fastest whether or not the beam is modulated in the $x$-direction. Because the mode with $k_{x}=k_{y}$ ultinately grows fastest, it is advantageous to choose $k_{x}^{2}$ close to $Y_{0}^{2} / 2$, bearing in mind that this modulation only aids in determining the cell siape. Furthermore the beam should not be modulated spatially at wavelengths comparable to the beam diameter, nor at such short wavelengths that the growth rate $a$ is nogligible or imoginary. Moreover, the beam should not be modulated in both the $x$ - and $y$-directions because the pattern formed at the end of the cell would resuli from a competition between the superimposed mode and the mode with maximus growth rate 5 wich would arke it difficult to interprot and analyze the data.

Experimentally, a beam from a singleaode ruby laser is allowed to traverso cells of carbon disulfide $\left(\mathrm{CS}_{2}\right)$. Before entering the $\mathrm{CS}_{2}$ cells, the beam is amplitude-modulated in one direction by means of a glass wedge of small angle. A glass wedge produces an intensity modulation of $16 \%$ of the form sin $\left(k_{x} x\right)$, and by using several wodges any spatial perturbation $k_{x}$ can be applied to the beam. The modulated intensity profile is allowed to self-focus in five $\mathrm{CS}_{2}$ cells which range in length from 50 to $150 \mathrm{~cm}$. For each $\mathrm{Cs}_{2} \mathrm{cell}$ the laser intensity is adjusted by means of different attenuating cells of copper sulfate until self-focusing is produced at the exit iace of each $\mathrm{CS}_{2}$ cell. These selffocusing thresho!d intensities are measured by means of a photodiode connected to an oscilloscope, and are determined by the onset of stimulated Raman scattering at the end of each cell which is detected by a second photodiode. Beam energies are measured with a calorimeter. These self-

focusing threshold intersities, along with photographs of the focal spots at the end of each $\mathrm{CS}_{2}$ cell from which $k_{x}$ and $k_{y}$ are measured, yield the relationship between the intensity and $k$.

A photograph of a self-focusing pattern that developed at the exit face of a $\mathrm{CS}_{2}$ cell is shown in Fig. 1. The k-vector of the instability mode is deternined by dividing $2 \pi$ by the spacing between the focal spots in the $x$-and $y$-directions yielding

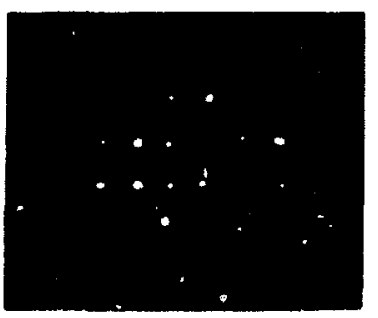

Fig. 1. A self-focusing pattern photographed at the cxit face of a $\mathrm{CS}_{2}$ cell. This patecrn originates because of thc rapid growth of a spatial perturbation whose k-vector components, $k_{x}$ and $k_{y}$, can be determincd by measuring the spacings botween the focal spots. 
$k_{x}$ and $k_{y}$, respectively. Fur the case shown in Fig. $1, k_{x}$ and $k_{y}$ are nearly equal and each $k$-vector cell contains one focal spot. At higher powers than threshold, the cell can divide further and more focal spots ar: formed.

The absolute magnitude of the $k$ vector which develops at the end of each $\mathrm{CS}_{2}$ cell is plotted as a function of threshold intensity in Fig. 2. Error bars are mainly because the intensity near the peak of the beam is not uniform, but Gaussian, leading to a vector dependence with position, and because of a nonlinear lens erfect due to the Gaussian profile. These effects are easily observed experimentally as the focal spots are compressed closer near the peak of the beam, and, rather than coinciding exactly with the peaks of the modulation which originally followed straight lines, the focal spors lie oll lines that bend toward the center of the beam. The Gaussian intensity profile causes a 2 to $10 \%$ correction in the k-vector (depending on components of the k-vector), while nonlinear lens effects are estimated to calse a vari-

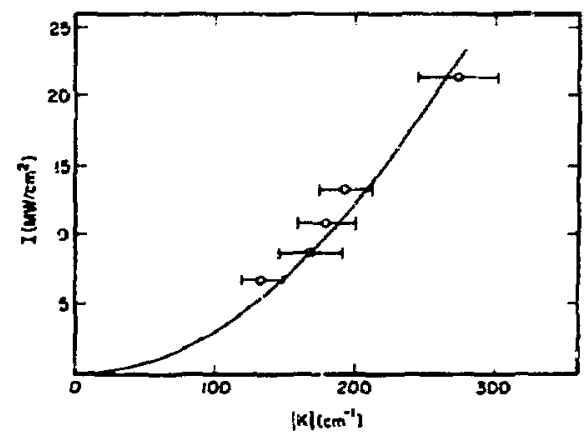

Fig. 2. The threshold intensity for selffocusing is ploceed as a function of $|k|$. The solid line shows that the intensity is dependent upon $k^{2}$ in agrecwent with instability thoory. ation of 3\%. In some cases a reading error in the position of the focal spots can lead to a 5t exror. Figure 2 shows that the intensity fits a $k^{2}$ dependence as shown by the solid line. The absolute coefficient between $I$ and $k^{2}$ as determined experimentally differs by a factor of 1.6 from the theoretical coefficient calculated by using the values of $\lambda=6943 \AA, n_{0}=1.62$, and $n_{2}=$ $1.8 \times 10^{-11} \mathrm{esu}$. The agreement with the absolute coefficient is satisfactory as the theory is only meant to appiy to beams of uniforn intensity.

Finally the threshold power for selffocusing is plotted as a function of the cell length in Fig. 3. The threshold power for self-focusing is inversely proportional to the cell length, a result predicted by Eq. 3 for high-power laser beams. This is a different result than that given by the theory of kelley ${ }^{6}$, which predicts that the self-focusing length is inversely dependent on the square root of the power minus one critical power--a result which applies to low-power laser beams. Note that Chilingarian ${ }^{7}$ demonstrated that the self-focusing

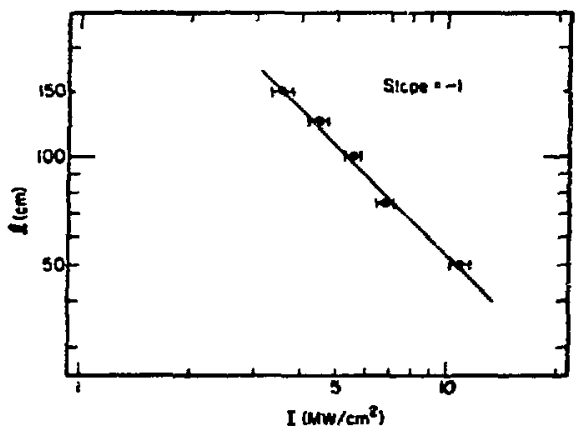

Fig. 3. The self-focusing length is plotted as a function of an average intensity. A slope of minus one indicares that the self-focusing length is inversely depondent on the intensity. The poak intensity is twice the average intensity plotted. 
length for inhomogeneous laser beams goes inversely with the power. In his case inhomogeneities were already present in the beam at the outset, and those with certain favorable characteristic frequencies selffocused easily, while in our case spatial inhomogeneities grow from the instabilities. Experimental data reported in this letter substantially verifies the theoretical model of suydam. 2

\section{REFERENCES}

1. A. J. Campillo, S. L. Shapiro, and B. R. Suydam, to be published.

2. B. R. Suydam, 1973 ASTM-NBS Symposium on Damage in Laser Materials, proceedings to be published.
3. V. I. Bespalov and V. I. Talanov, Zh. Eksperim. i Teor. Fiz. Pis'ma Red. 3 , 471 (1966) [JETP Letters 3,307 (1966)].

4. Note that $k$ is the wave number vector of the perturbation, which we presume to have been Fourier analysed in space; it is not $\omega / c$.

5. When the beam was modulated experimentally in both directicns, there was a strong tendency for the mode with the highest growth rate to dominate over any such superimposed mode.

6. P. L. Kelley, Phys. Rev. Letters 15, $1005(1965)$.

7. Y. S. Chilingarian, 2h. Eksperimi Teor. Fiz. 55, 1589 (1968) [Soviet Physics JETP $\overline{28}, 832$ (i969)]. 